\title{
VPLIV NEFORMALNEGA IZOBRAŽEVANIA NA RAZVOJ SPRETNOSTI IN KOMPETENC
}

\section{POVZETEK}

V uvodnem teoretskem delu študije bomo najprej razjasnili temelje dileme in osnovne pojme izobraževanja odraslih. Zastavili si bomo vprašanje vpetosti Memoranduma o vseživljenjskem učenju v kontinuiteto prizadevanj za višjo stopnjo razvoja posameznika in njegovih zmožnosti. Pogledali bomo, ali ima in zakaj ima izobraževanje odraslih kompenzacijsko vlogo. To bo osnova tudi za raziskovanje pomena neformalnega izobraževanja za razvoj spretnosti v empiričnem delu. Odločili smo se za dve raziskovalni vprašanji, ki ju bomo analizirali na podlagi razpoložljivih podatkov raziskave PIAAC, pri čemer bo težišče na analizi povprečja vseh vključenih držav, vključili pa bomo tudi analizo podatkov za nekaj posameznih držav. Rezultati kažejo na velik pomen neformalnega izobraževanja za dosežke na vseh treh področjih, kjer smo merili stopnje doseženih spretnosti. Vključevanje $v$ neformalno izobraževanje pri tistih z nižjo izobrazbo je imelo bolj pozitivne učinke kot pri tistih s srednjo in višjo izobrazbo. Pomembna ugotovitev je tudi, da neformalnemu izobraževanju, vezanemu na poklic in delo, ne kaže namenjati večje pozornosti kot tistemu, ki poteka mimo teh potreb. Pri nekaterih izmerjenih spretnostih se je pokazalo, da so v vseh primerih dosegali boljše rezultate tisti, ki so bili vključeni $v$ neformalno izobraževanje, ki ni bilo povezano s potrebami dela in poklica.

Ključne besede: spretnosti odraslih, neformalno izobraževanje, kompetence, značilnosti delovnega mesta, PIAAC

\section{THE IMPACT OF NON-FORMAL EDUCATION ON THE DEVELOPMENT OF SKILLS AND COMPETENCIES - ABSTRACT}

In the introduction of this study, we first clarify the fundamental dilemma and the basic concepts of adult education. We will analyse the integration of the Memorandum on Lifelong Learning in the continuity of efforts toward a higher level of development of the individual and his or her capabilities. We will observe whether or not an adult has a compensatory role, the results of which will be the basis for exploring the importance of non-formal education for skills development in the empirical section of our research. We will analyze two research questions using data available in the PIAAC research dataset, with a focus on an analysis of the average of all countries involved. In some cases, we will also include an analysis of data for some individual countries. The results demonstrate the significance of non-formal education for achievements in all three areas that were used to measure skills achievement. For those with less

Red.prof. dr. Janko Muršak, Filozofska fakulteta Univerze v Ljubljani, janko.mursak@ guest.arnes.si Doc.dr. Marko Radovan, Filozofska fakulteta Univerze v Ljubljani, marko.radovan@ff.uni-lj.si 
education, engaging in non-formal education produced more positive effects than it did for those with secondary and higher education. Importantly, we have established that non-formal education connected with work does not have more impact than the same education pursued for more personal reasons. For some skills we measured, the data have demonstrated that, in all cases, adults who have participated in non-work-related non-formal education achieved better results than those who engaged in work-related non-formal education.

Keywords: adults' skills, non-formal education, competencies, workplace, PIAAC

\section{UVOD}

Z udejanjanjem koncepta vseživljenjskega učenja se zmanjšuje možnost razločevanja med tistimi spretnostmi in $\mathrm{z}$ njimi povezanimi kompetencami, ki jih posameznik pridobi $\mathrm{v}$ mladosti oziroma $v$ formalnem izobraževanju, in tistimi, ki so rezultat neformalnega izobraževanja in priložnostnega učenja v različnih delovnih in življenjskih situacijah. To pa še ne pomeni, da je za razvoj splošnih spretnosti in kompetenc formalno izobraževanje manj pomembno kot za razvoj in ohranjanje stopnje pismenosti in njene nadgradnje $\mathrm{v}$ odraslosti. Koncept vseživljenjskega učenja, ki je postal podmena vseh razprav o politiki in strategijah razvoja izobraževanja, govori nasprotno.

Koncept vseživljenjskega učenja prinaša tudi spremembe, ki zadevajo prenos kulturnih vrednot in klasičnih modelov kultivacije intelekta. Poudarjanje učenja skozi vse življenje razume kot prestrukturiranje ciljev izobraževanja $v$ mladosti od tega, da si posameznik oblikuje celovito znanje o obstoječi kulturi, svetu in življenju, »ustroju sveta«, kot bi lahko rekli, k ciljem, ki naj posamezniku omogočijo nenehno učenje kot prilagajanje novim potrebam in imperativom trenutnega ekonomskega, socialnega in kulturnega okolja. Klasična pozicija izobraženega posameznika, torej kritična pozicija bolj ali manj neodvisnega intelektualca, ki s kritično distanco, oborožen z vedenjem in poznavanjem tradicije, vzpostavlja sebe in svoje mesto v družbi in kulturi skozi ustrezno refleksijo in se temu ustrezno postavlja po robu manipulacijam in prizadevanjem sodobne ekonomije, se spreminja $\mathrm{v}$ samosprejetje pozicije, $\mathrm{v}$ kateri je posameznik razumljen kot potencialni potrošnik ekonomskega in političnega marketinga $v$ funkciji dobro delujočega ekonomskega in družbenega sistema. Takšna logika se ne nazadnje neposredno kaže tudi v opredelitvah ključnih kompetenc, kot jih navaja zdaj že skorajda zgodovinski dokument Memorandum o vseživljenjskem učenju. Poudarja predvsem dva cilja, in sicer aktivno državljanstvo in povečevanje zaposljivosti: »Aktivno državljanstvo se osredotoča na to, koliko in kako ljudje sodelujejo $\mathrm{v}$ vseh sferah družbenega in gospodarskega življenja, ter na priložnosti in tveganja, s katerimi se soočajo, ko to poskušajo. Osredotoča se tudi na posledično stopnjo pripadnosti tej družbi in na možnost odločanja v njej.« (Memorandum o vseživljenjskem učenju, 2000, str. 5)

Nastala je situacija, ko je učenje in izobraževanje postalo imperativ, ki podreja posameznika dvojni logiki, in sicer logiki zaposljivosti in logiki »družbene integracije«, pri čemer v ospredje stopa družbeno nekonflikten posameznik, kar omogoča njegovo ustrezno podreditev ekonomski logiki in logiki družbenega razvoja. Naslonili se bomo na Ozval- 
dovo zahtevo (1928), ki jo sodobna andragoška teorija poudarja kot prioritetno nalogo šole, namreč da naj bo cilj izobraževanja razvoj vedoželjnosti, sposobnosti za samostojno učenje. To pa je mogoče doseči le z redukcijo snovi in $\mathrm{z}$ ustreznim načinom dela $\mathrm{v}$ šoli. Zelo izrazito je to zahtevo Ozvald formuliral v Prispevku k idejnim temeljem šolskega zakona iz leta 1928. Zahteva bi lahko postala moto tudi za sodobne reforme izobraževanja: »To se pravi, šola bi mladine ne smela prenasičevati z znanjem, temveč otroka in mladostnika tako voditi, da se prej ali slej ne bo od vsega, kar mu je priskutila, za vselej veselo poslovil, češ, 'Bog s teboj, šolska ropotija!', ampak da v njem vzbrsti lakota po nadaljnjem izobraževanju - v veliki šoli življenja.«(Ozvald, 1928, str. 13)

Opredelitev izobraženosti in izobrazbe je tako povezana $\mathrm{z}$ »andragoško « dimenzijo oziroma vseživljenjskostjo izobraževanja. »Saj je izobražen samo tisti, ki se neprestano izobražuje ter svoj odnošaj do raznovrstnih vrednot, to je do tega, kar se imenuje lepo, dobro, prav, kulturno, sveto ... in kar je pač glavno gibalo dejanja in nehanja, vedno bolj izpopolnjuje in poglablja.«(Ozvald, 1927, str. 199) Izobrazba je torej proces, še posebej pa to velja za splošno izobrazbo, do katere pot pelje edinole prek poklica in poklicne izobrazbe. »S tem pa je tudi ugotovljena poglavitna smer vsemu zares izobraževalnemu delu. In ta smer drži: od strokovne (poklicne) k splošni izobrazbi, a ne narobe!« (Ozvald, 1922, str. 3) Seveda moramo tukaj ponovno poudariti, da pojem poklica in s tem povezane poklicne ali strokovne izobrazbe Ozvaldu ne pomeni zaposlitve ali dela v smislu današnje (zlo) rabe pojma poklic, zreduciranega na delo, ki ga posameznik opravlja, temveč poklica kot po-klicanosti, poslanstva, ki ga človek izpolnjuje skozi svoje delo in zaposlitev. Splošna izobrazba je torej izobrazba, do katere pride posameznik le v svoji celokupni življenjski dejavnosti in je ni mogoče kvantitativno določiti, še manj pa jo je mogoče razumeti ločeno od osnovne ali poklicne izobrazbe. Splošna izobrazba je torej izobrazba »par exellence«, katere nujni in sestavni del sta tako poklicna ali strokovna kot osnovna izobrazba. Njena temeljna značilnost pa je razvojnost in vseživljenjskost.

\section{Ali ima izobraževanje odraslih kompenzacijsko vlogo?}

$\mathrm{V}$ tej zvezi ostaja zanimiva ugotovitev, da je izobraževanje $\mathrm{v}$ mladosti tudi $\mathrm{v}$ konceptu, ki ga opisujemo, ključen dejavnik razvoja posameznika in da so pričakovanja, kako je mogoče v odraslosti kompenzirati zamujeno v mladosti, neutemeljena, da ne rečemo iluzorna. Gre za to da, da bolj ko je z vidika razvoja, socialne in delovne vključenosti za posameznika pomemben tisti del vseživljenjskega učenja/izobraževanja, ki poteka v dobi odraslosti, bolj pomembno ali celo odločilno postaja zanj izobraževanje v mladosti. Tako imenovano kompenzacijsko izobraževanje odraslih (Krajnc, 1979) v svoji funkciji odpravljanja izobrazbenih primanjkljajev ni izpolnilo pričakovanj z začetka druge polovice 20 . stoletja. Nasprotno, pokazalo se je, da se v mladosti izobrazbeno prikrajšani posamezniki v dobi odraslosti prav tako manj vključujejo v izobraževanje in da izobraževanje odraslih socialno neenakost, ki izvira iz različne udeležbe mladih v izobraževanju, prej poglablja, kot jo zmanjšuje. Tako podatki za Slovenijo kažejo, da je bilo v letu 1998 med tistimi s terciarno izobrazbo izobrazbeno dejavnih kar 72 odstotka odraslih, medtem ko je bilo med njimi tistih, ki so končali med pet in osem razredov osnovne šole, le 11 odstotkov 
(Mohorčič Špolar idr., 2001). Tudi obširna analiza, ki jo je izvedla P. Kelava (2003), je pokazala na navidezni paradoks, »da se razlike v izobraževanju povečujejo tako, da se kot odrasli dosti več izobražujejo tisti posamezniki, ki imajo višjo izhodiščno izobrazbo (le-to pa so verjetno pridobili že v začetnem izobraževanju), in mnogo manj tisti posamezniki, ki imajo izhodiščno izobrazbo nižjo. Ne le, da se višje izobraženi izobražujejo več, izobraževanje jim je tudi bližje in lažje (samoizobraževanje jim ni tuje, ne ustrašijo se samostojnega iskanja virov o temah, ki jih zanimajo, in podobno), te navade so med člani družine navadno 'nalezljive'.« (Kelava, 2003, str. 99)

Tako se torej tudi v udeležbi v izobraževanju kaže zakonitost, da je enakost možnosti kategorija, ki je že v izhodišču vezana na izobraževanje. V tem smislu tudi Sardoč (2013) ugotavlja, da je pri enakosti možnosti treba ločevati dva vidika, in sicer primarnega, ki je povezan s pridobivanjem kvalifikacij in izobrazbe oziroma dostopa do nje, in derivativnega, ki je vezan na pridobivanje selektivnih družbenih položajev.

»Vzorčna povezanost drugega vidika (t. i. derivativni vidik) s primarnim vidikom enakih možnosti kaže, da so enake možnosti na področju vzgoje in izobraževanja osnovno izhodišče zagotavljanja enakosti ter nepovezanosti posameznikovega družbenega položaja z njegovim spolom, raso, spolno usmerjenostjo, veroizpovedjo, etično pripadnostjo itn.«(Sardoč, 2013, str. 60)

Ne gre le za selektivne družbene položaje, kot to opozarja citirani avtor, temveč tudi za selektivnost pri vključevanju v izobraževanje.

V skladu z omenjenimi premisleki se je razvijala tudi ideja o vseživljenjskem učenju; ta je prešla iz široko zasnovane ideje o izobraževanju kot osvobajajoči dejavnosti, ki - poleg tega, da ponuja »drugo možnost«, o čemer smo že govorili -, prehaja tudi k vse ožjemu konceptu učenja v njegovi pragmatični funkciji. S tega vidika bi bil nujno pogledati še prakso vključevanja v izobraževanje, saj lahko predpostavljamo, da višja raven izobrazbe, pridobljene v mladosti, odločilno vpliva tudi na vsebinsko obarvanost, s kakršno se skozi življenje srečujejo posamezniki v svoji izobraževalni dejavnosti. Obširna raziskava, ki so jo o tej temi opravili v Franciji, je pokazala, da $\gg$ v Evropski uniji prevladuje ekonomska logika: učenje je sredstvo konkurenčnosti podjetja in zaposljivosti posameznikov, ki zanemarja permanentno izobraževanje kot globalno vizijo. [...] Opazimo lahko, da je učenje kot 'človekova pravica' prepustilo pobudo učenju kot 'sredstvu za ekonomski in socialni razvoj'. Enako kot se je učenje zreduciralo na 'aplikativen vidik humanističnih znanosti' in se ne razume več kot 'pomembna izkušnja $\mathrm{v}$ zvezi s temeljnimi človeškimi potrebami.' (Ardouin, 2006, str. 155) Kolikor bolj je posameznik podvržen trgu in ohranjanju konkurenčnosti, toliko bolj torej zanj velja, da se izobraževanje ne razume kot sredstvo za zadovoljevanje temeljnih človekovih (humanističnih) potreb, temveč kot pripomoček za ohranjanje konkurenčnosti. Imamo torej opravka z dvojno blokado: manj izobraženi se manj vključujejo v izobraževanje, njihovo izobraževanje pa je bolj podvrženo tržnim zakonitostim (konkurenčnosti). 


\section{Vključenost $v$ izobraževanje in razvoj splošnih spretnosti in kompetenc}

Povezave med vključenostjo v neformalno izobraževanje in doseženo stopnjo formalne izobrazbe so bile že večkrat dokazane in so v strokovni literaturi že tematizirane. Manj raziskano pa je, koliko se posamezniki z enakimi ravnmi formalne izobrazbe razlikujejo $\mathrm{v}$ doseženi stopnji razvoja spretnosti in kompetenc glede na obseg vključenosti v razne oblike neformalnega izobraževanja. Ugotavljanje teh razlik je zahtevno, ker je merjenje kompetenc, ki presegajo temeljne spretnosti, že samo po sebi izjemno zapleteno. Še posebej to velja za tacitne spretnosti in kompetence, ki uhajajo merskim instrumentom in jih je mogoče prepoznati le posredno. Če torej ugotavljamo, da je vključenost v neformalno izobraževanje pri tistih z višjimi stopnjami izobrazbe empirično dokazljiv fenomen, pa ostaja nepotrjeno, ali je obseg vključenosti v neformalno izobraževanje ob isti stopnji dosežene formalne izobrazbe povezan tudi z višje razvitimi kompetencami in spretnostmi. Predpostavka je, da ta povezava obstaja.

Pogosta kritika sodobnega koncepta vseživljenjskega učenja, kot je razvit v Memorandumu EU o vseživljenjskem učenju - omenjali smo jo že na začetku naše razprave -, pa je, da daje poudarek predvsem tistemu izobraževanju, ki je v funkciji dela in socialne vključenosti, manj pa tistemu, ki je povezano z razvojem osebnosti in dvigom kakovosti življenja zunaj dela in socialnega angažmaja. Nedavno sprejeti nacionalni program izobraževanja odraslih pomeni poskus, kako to neuravnoteženost zmanjšati.

Cilji in prioritete, ki jih program navaja, se nanašajo na:

- dvig izobrazbene ravni prebivalstva in raven temeljih zmožnosti,

- povečanje zaposljivosti aktivnega prebivalstva,

- izboljšanje možnosti za učenje in vključevanje v izobraževanje,

- izboljšanje splošne izobraženosti (Resolucija o nacionalnem programu izobraževanja odraslih v RS za obdobje 2013-2020, 2013, str. 9765).

Ne glede na tako zastavljene cilje, ki obetajo poudarek predvsem razvoju splošnih spretnosti in zmožnosti, pa se dve od treh prednostnih področij osredotočata na dvig formalne izobrazbe in na izobraževanje za potrebe trga dela in le eno na področje krepitve splošnega izobraževanja prebivalstva. Predvidena javna sredstva prav tako dajejo prednost neposredno izobraževanju za potrebe dela in zaposlovanja (46 odstotkov sredstev), manj pa za splošno izobraževanje in dvig formalne izobrazbe (vsako od teh dveh področij bo prejelo po 20 odstotkov sredstev), pri čemer je tudi dvig formalne izobrazbe v velikem delu omejen na formalno poklicno in strokovno izobrazbo (Resolucija o nacionalnem programu izobraževanja odraslih v RS za obdobje 2013-2020, 2013). Taka delitev kaže, da ni pričakovati večjega izboljšanja izobraževalne dejavnosti za zvišanje ravni splošnih spretnosti in kompetenc.

Zaradi tega je z vidika razvoja izobraževanja odraslih, kot ga predvideva v obliki resolucije sprejeti nacionalni program izobraževanja odraslih, še posebno pomembno odgovoriti na vprašanje, ali je mogoče navedena prednostna področja, zlasti prvo in tretje, združiti oziroma pripravljati take možnosti, ki bodo ponudile razvoj temeljnih spretnosti, kot jih 
merimo in primerjamo na mednarodni ravni, sočasno ali pa vztrajati na ločeni obravnavi in pripravi programskih shem, ki področij ne bodo povezovale.

Vprašanje razvoja splošnih spretnosti in dviga splošne izobrazbene ravni prebivalstva pa je še toliko bolj aktualno ob rezultatih proučevanja ravni pismenosti mladih, kjer se po zadnjih podatkih OECD-jeve raziskave PISA za leto 2012 (PISA, 2012) ugotavlja njen upad. To je toliko bolj skrb zbujajoče, ker so tudi rezultati merjenja pismenosti odraslih, ki je bilo v Sloveniji resda opravljeno že leta 1998, pokazali razmeroma nizke ravni pismenosti odraslih, in to tudi pri tistih, pri katerih bi glede na raven dosežene izobrazbe pričakovali višje ravni pismenosti (Možina, 2000).

Da pa bi lahko odgovorili na dilemo, ali in kako je vključevanje v izobraževanje glede na cilj - potrebe dela ali splošni razvoj pismenosti neodvisno od potreb dela (kar ustreza tretjemu oziroma prvemu prednostnemu področju) - povezano z doseganjem višje stopnje pismenosti, moramo neposredno proučiti, ali so med tistimi, ki se vključujejo v neformalno izobraževanje zaradi potreb dela, in tistimi, ki se vanj vključujejo v približno enakem obsegu mimo potreb dela, opazne razlike v izmerjenih temeljnih spretnostih na različnih področjih. Zaradi tega je smiselno posebej ugotoviti, ali na razvoj kompetenc in doseženih ravni pisnih spretnosti vpliva tudi to, ali so posamezniki v neformalno izobraževanje vključeni zaradi potreb dela ali iz osebnih oziroma z delom nepovezanih razlogov.

Kot smo videli, na razvoj in upadanje temeljnih in specifičnih spretnosti vpliva več dejavnikov, med katerimi je ob enaki stopnji formalne izobrazbe in vključenosti v izobraževanje treba posebej omeniti še dva: starost in zaposlitveni status. Teza je, da je zaposlitveni status lahko močnejši dejavnik (ne)razvoja kot samo staranje oziroma starost. Zaradi tega je treba posebej pogledati, ali so razlike v izmerjenih spretnostih odvisne od starosti ali zaposlitvenega statusa (zaposleni in začasno ali dolgoročno nezaposleni). Ob tem pa se postavlja tudi vprašanje, ali sta značilnost dela in panoga dejavnosti povezani z ravnijo doseženih spretnosti in kompetenc posameznika. Mislimo na stopnjo avtonomije pri delu, razvitost učnega okolja, delo v (ne)učeči se organizaciji z (ne)razvitim HRM, delo v javnem ali zasebnem sektorju in samozaposlenost.

Proučitev navedenih povezav in odvisnosti bo omogočila nova spoznanja o zakonitostih razvoja splošnih spretnosti in kompetenc, ki bodo služila kot izhodišče za konceptualne rešitve pri vodenju in načrtovanju formalnega in neformalnega izobraževanja. Poleg izobraževanja se bo pokazal še pomen preostalih dejavnikov vseživljenjskega učenja, ki prispevajo k višji stopnji razvitosti temeljnih in specifičnih spretnosti in kompetenc, kot jih je mogoče empirično meriti.

\section{RAZISKAVA PIAAC}

Raziskava PIAAC (Programme for the International Assessment of Adult Competences) poteka v okviru OECD in se umešča v kontekst uresničevanja Strategije o kompetencah za delo (OECD Skills Strategy), ki jo je svet ministrov OECD (MCM) sprejel maja 2012. 
Slovenija se je v projekt PIAAC vključila leta 2013, v neposredno testiranje izbranih kompetenc pa je bilo vključenih več kot pet tisoč odraslih iz vseh slovenskih regij, starih od 16 do 65 let. Izsledki slovenskega dela raziskave bodo objavljeni v drugi polovici leta 2016.

Raziskava PIAAC meri nekatere spretnosti in kompetence, ki jih posameznik uporablja tako pri delu kot $\mathrm{v}$ zasebnem življenju, in sicer na treh področjih:

- reševanje problemov v tehnološko bogatih okoljih (zmožnost najti, izbrati, ovrednotiti in uporabiti informacije s pomočjo računalnika za reševanje problemov);

- matematične spretnosti (zmožnost uporabiti, interpretirati in posredovati matematične informacije ter zamisli);

- bralne spretnosti (osnovne bralne spretnosti, kot so prepoznavanje besed, razumevanje stavkov in zmožnost razumeti ter uporabiti informacije iz različnih besedil).

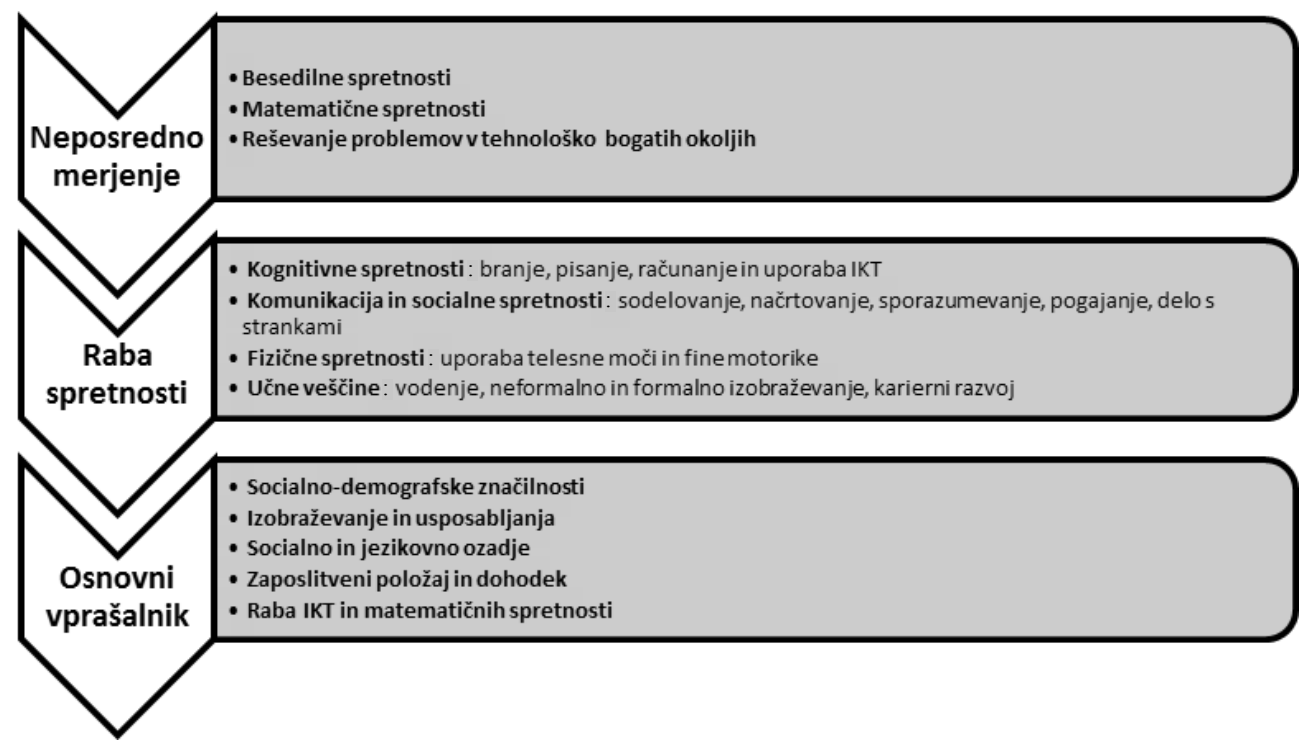

Slika 1: Elementi raziskave spretnosti odraslih (vir: spletna stran PIAAC')

Posredno pa raziskava PIAAC proučuje tudi nekatere druge spretnosti, kot je uporaba kognitivnih spretnosti, komunikacijske in socialne spretnosti, fizične spretnosti in učenje učenja. Zbiranje podatkov poteka s pomočjo vprašalnika, ki je sestavljen iz osnovnega vprašalnika in testnih nalog (spletna stran PIAAC). 


\section{METODOLOGIJA}

Za statistično analizo smo uporabili podatke, zbrane v mednarodni bazi PIAAC (Survey of Adults Skills, 2012), ki vsebuje podatke okoli 166.000 odraslih iz 24 držav, ki so sodelovale v prvem krogu raziskave. Statistična analiza je bila opravljena s pomočjo aplikacije International Database (IDB) Analyzer (IEA IDB Analyzer ver. 3.1.25). International Database Analyzer je računalniški program za analizo anketnih podatkov projekta PIAAC - Programa za mednarodno ocenjevanje kompetenc odraslih. Ne gre za samostojen program, temveč za uporabniški vmesnik oziroma nadgradnjo analitičnega orodja IBM SPSS Statistics, ki so ga pripravili pri IEA DPC (International Association for the Evaluation of Educational Achievement - Data Processing and Research Center). IDB Analyzer omogoča analizo kompleksnega večstopenjskega vzorca in izračun deskriptivnih statistik pismenosti, ki so merjene z več spremenljivkami (Item Response Theory), pri čemer izračunava tudi standardne napake, na podlagi katerih je možno izračunati intervale zaupanja oziroma opravljati tudi sklepanja iz vzorca na populacijo.

\section{Raziskovalna vprašanja}

V članku želimo odgovoriti na naslednji dve raziskovalni vprašanji:

- Koliko se posamezniki z enakimi ravnmi formalne izobrazbe razlikujejo v doseženi stopnji razvoja spretnosti in kompetenc glede na obseg vključenosti v neformalno izobraževanje?

- Ali so med tistimi, ki se v neformalno izobraževanje vključujejo zaradi potreb dela, in tistimi, ki se vanj vključujejo mimo potreb dela, opazne razlike v izmerjenih temeljnih spretnostih na različnih področjih?

\section{REZULTATI IN RAZPRAVA}

\section{Razlike $v$ izmerjenih spretnostih glede na vključenost $v$ neformalno izobraževanje po doseženi izobrazbi}

V uvodnem delu študije smo postavili predpostavko, da so povprečni dosežki pri posameznih vrstah merjenih spretnosti močno povezni s stopnjo izobrazbe, da pa se v povprečju tudi med tistimi, ki imajo enako stopno izobrazbe, pojavljajo razlike glede na to, koliko so po končanem šolanju še naprej izobraževalno dejavni. V spodnji tabeli prikazujemo podatke za vključene države, ločeno po stopnjah izobrazbe. Primerjali bomo skupno povprečje vključenih držav, posebej pa še dve državi, in sicer sosedo Italijo ter po razvitosti in velikosti bližjo Češko. Najprej si bomo pogledali podatke za bralne spretnosti. 
Tabela 1.1: Razlike $v$ bralnih spretnostih po stopnii izobrazbe glede na vključenost $v$ neformalno izobraževanje (povprečja, starost 16-65 let)

\begin{tabular}{|c|c|c|c|c|c|c|c|c|c|c|c|c|}
\hline \multirow[b]{3}{*}{ DRŽAVA } & \multicolumn{4}{|c|}{ Nižja izobrazba } & \multicolumn{4}{|c|}{ Srednja izobrazba } & \multicolumn{4}{|c|}{ Višja izobrazba } \\
\hline & \multicolumn{2}{|c|}{ ni vključen } & \multicolumn{2}{|c|}{ vključen } & \multicolumn{2}{|c|}{ ni vključen } & \multicolumn{2}{|c|}{ vključen } & \multicolumn{2}{|c|}{ ni vključen } & \multicolumn{2}{|c|}{ vključen } \\
\hline & M & S.E. & M & S.E. & M & S.E. & M & S.E. & M & S.E. & M & S.E. \\
\hline Belgija & 232,7 & $(1,9)$ & 248,3 & $(4,2)$ & 266,7 & $(1,4)$ & 272,9 & $(1,9)$ & 295,4 & $(1,7)$ & 304,0 & $(1,4)$ \\
\hline Kanada & 225,1 & $(1,8)$ & 241,1 & $(3,5)$ & 266,9 & $(1,5)$ & 279,9 & $(1,6)$ & 278,0 & $(1,0)$ & 298,0 & $(0,9)$ \\
\hline Češka & 239,1 & $(4,6)$ & 257,1 & $(9,0)$ & 265,7 & $(1,4)$ & 274,7 & $(1,4)$ & 295,0 & $(2,8)$ & 300,8 & $(2,5)$ \\
\hline Danska & 226,3 & $(2,7)$ & 242,2 & $(3,1)$ & 260,1 & $(1,5)$ & 273,0 & $(1,2)$ & 281,8 & $(2,0)$ & 295,6 & $(1,1)$ \\
\hline Estonija & 242,7 & $(2,2)$ & 257,4 & $(3,7)$ & 264,1 & $(1,3)$ & 280,6 & $(1,4)$ & 277,9 & $(1,4)$ & 292,4 & $(1,1)$ \\
\hline Finska & 243,4 & $(3,0)$ & 258,7 & $(4,4)$ & 273,7 & $(2,0)$ & 290,1 & $(1,8)$ & 294,9 & $(1,9)$ & 310,3 & $(1,1)$ \\
\hline Francija & 222,6 & $(1,3)$ & 235,6 & $(2,8)$ & 260,4 & $(1,0)$ & 265,6 & $(1,3)$ & 290,0 & $(1,4)$ & 300,1 & $(1,1)$ \\
\hline Nemčija & 224,0 & $(3,1)$ & 244,2 & $(4,9)$ & 253,9 & $(1,5)$ & 270,6 & $(1,5)$ & 286,4 & $(1,9)$ & 299,0 & $(1,4)$ \\
\hline Irska & 231,2 & $(2,1)$ & 235,3 & $(3,0)$ & 266,0 & $(2,0)$ & 274,4 & $(2,8)$ & 274,0 & $(1,6)$ & 289,1 & $(1,3)$ \\
\hline Italija & 228,9 & $(1,8)$ & 237,1 & $(4,1)$ & 258,5 & $(1,5)$ & 273,8 & $(2,1)$ & 273,7 & $(2,6)$ & 288,2 & $(2,4)$ \\
\hline Japonska & 254,5 & $(3,2)$ & 258,8 & $(5,8)$ & 285,6 & $(1,1)$ & 293,4 & $(1,5)$ & 308,1 & $(1,6)$ & 316,2 & $(0,9)$ \\
\hline Koreja & 226,5 & $(1,8)$ & 243,8 & $(2,9)$ & 265,7 & $(1,3)$ & 279,4 & $(1,3)$ & 283,8 & $(1,4)$ & 294,0 & $(1,1)$ \\
\hline Nizozemska & 242,7 & $(2,0)$ & 256,3 & $(2,6)$ & 283,3 & $(1,9)$ & 291,5 & $(1,4)$ & 303,7 & $(2,6)$ & 313,4 & $(1,5)$ \\
\hline Norveška & 235,8 & $(2,9)$ & 245,2 & $(5,2)$ & 269,1 & $(1,6)$ & 274,6 & $(1,7)$ & 284,6 & $(1,9)$ & 300,5 & $(1,1)$ \\
\hline Poliska & 226,8 & $(2,5)$ & 246,7 & $(5,4)$ & 253,5 & $(1,1)$ & 268,8 & $(2,0)$ & 286,5 & $(1,6)$ & 299,1 & $(1,4)$ \\
\hline Slovaška & 228,8 & $(2,2)$ & 256,1 & $(8,1)$ & 270,1 & $(0,9)$ & 284,6 & $(1,9)$ & 291,7 & $(1,9)$ & 297,5 & $(1,9)$ \\
\hline Španija & 222,4 & $(1,5)$ & 237,4 & $(2,0)$ & 256,4 & $(1,9)$ & 266,4 & $(2,0)$ & 275,2 & $(2,0)$ & 284,8 & $(1,2)$ \\
\hline Švedska & 232,9 & $(2,9)$ & 256,4 & $(3,8)$ & 262,7 & $(1,9)$ & 281,5 & $(1,5)$ & 289,5 & $(2,5)$ & 308,6 & $(1,1)$ \\
\hline VB & 223,3 & $(2,6)$ & 232,2 & $(6,6)$ & 261,7 & $(1,6)$ & 276,8 & $(1,8)$ & 284,0 & $(2,4)$ & 300,3 & $(1,7)$ \\
\hline ZDA & 212,7 & $(2,7)$ & 220,1 & $(5,3)$ & 253,0 & $(1,8)$ & 269,7 & $(1,9)$ & 280,0 & $(1,8)$ & 296,3 & $(1,6)$ \\
\hline Povprečje & 231,1 & $(0,6)$ & 245,5 & 1,09 & 264,8 & 0,35 & 277,1 & $(0,4)$ & 286,7 & $(0,4)$ & 299,4 & $(0,3)$ \\
\hline
\end{tabular}

Opomba: Nižja izobrazba zajema stopnje ISCED: 1, 2 in 3C kratki p. Srednja izobrazba zajema stopnje ISCED: 3A, 3B, 3C dolgi $p$ in 4. Višja izobrazba zajema stopnje ISCED: 5A, 5B in 6.

Vir: Survey of Adults Skills (PIAAC, 2012).

Iz tabele je jasno razvidno, da tudi naši podatki dokazujejo povezavo med izobraževalno dejavnostjo po končanem rednem šolanju in kasnejšim vključevanjem v različne oblike neformalnega izobraževanja. Na podlagi dobljenih podatkov lahko sklepamo, da so pri bralnih spretnostih razlike največje pri tistih z nižjo stopnjo izobrazbe $(14,4)$, srednje pri tistih s srednjo $(13,3)$ in najmanjše pri tistih s doseženo višjo stopno izobrazbe $(12,4)$. Primerjali smo tudi dve posamezni državi, in sicer Češko in Italijo. Podobna situacija kot pri povprečju se pokaže pri čeških podatkih, kjer so razlike največje pri nižji $(19,0)$, manjše pri srednji $(9,0)$ in najmanjše pri višji stopnji izobrazbe $(5,8)$. Italijanski podatki kažejo nekoliko drugačno sliko, saj so ob sicer nižjih povprečjih razlike najmanjše pri nižji stopnji izobrazbe $(8,2)$ ter skoraj izenačene pri srednji $(15,3)$ in višji $(14,5)$ stopnji izobrazbe.

S pomočjo naslednje tabele si bomo poskušali odgovoriti na vprašanje, kako je vključenost $\mathrm{v}$ neformalno izobraževanje povezana $\mathrm{z}$ dosežki na področju matematičnih spretnosti. 
Tabela 1.2: Razlike $v$ matematičnih spretnostih po stopnji izobrazbe glede na vključenost $v$ neformalno izobraževanje (povprečja, starost 16-65 let)

\begin{tabular}{|c|c|c|c|c|c|c|c|c|c|c|c|c|}
\hline \multirow[b]{3}{*}{ DRŽAVA } & \multicolumn{4}{|c|}{ Nižja izobrazba } & \multicolumn{4}{|c|}{ Srednja izobrazba } & \multicolumn{4}{|c|}{ Višja izobrazba } \\
\hline & \multicolumn{2}{|c|}{ ni vključen } & \multicolumn{2}{|c|}{ vključen } & \multicolumn{2}{|c|}{ ni vključen } & \multicolumn{2}{|c|}{ vključen } & \multicolumn{2}{|c|}{ ni vključen } & \multicolumn{2}{|c|}{ vključen } \\
\hline & $M$ & S.E. & M & S.E. & M & S.E. & M & S.E. & $M$ & S.E. & $M$ & S.E. \\
\hline Belgija & 234,2 & $(2,1)$ & 252,8 & $(4,2)$ & 270,6 & $(1,4)$ & 280,1 & $(2,0)$ & 299,6 & $(2,0)$ & 311,6 & $(1,3)$ \\
\hline Kanada & 211,9 & $(2,4)$ & 228,3 & $(3,9)$ & 256,6 & $(1,8)$ & 270,0 & $(1,8)$ & 271,1 & $(1,3)$ & 290,7 & $(1,0)$ \\
\hline Češka & 230,8 & $(3,9)$ & 249,0 & $(8,3)$ & 267,1 & $(1,6)$ & 276,8 & $(1,6)$ & 301,9 & $(2,7)$ & 310,3 & $(2,7)$ \\
\hline Danska & 233,4 & $(3,3)$ & 248,3 & $(3,0)$ & 269,4 & $(1,7)$ & 281,3 & $(1,3)$ & 290,1 & $(2,0)$ & 305,3 & $(1,2)$ \\
\hline Estonija & 232,8 & $(2,1)$ & 250,3 & $(3,6)$ & 261,4 & $(1,2)$ & 277,9 & $(1,4)$ & 279,1 & $(1,4)$ & 291,7 & $(1,1)$ \\
\hline Finska & 240,5 & $(3,0)$ & 254,9 & $(4,5)$ & 267,0 & $(1,9)$ & 282,9 & $(1,7)$ & 293,9 & $(2,3)$ & 306,0 & $(1,3)$ \\
\hline Francija & 205,3 & $(1,4)$ & 224,0 & $(3,0)$ & 251,2 & $(1,1)$ & 260,2 & $(1,3)$ & 288,6 & $(1,4)$ & 302,8 & $(1,3)$ \\
\hline Nemčija & 215,6 & $(3,7)$ & 234,8 & $(5,6)$ & 254,9 & $(1,7)$ & 273,3 & $(1,8)$ & 293,0 & $(2,4)$ & 305,6 & $(1,5)$ \\
\hline Irska & 216,7 & $(2,4)$ & 223,8 & $(4,0)$ & 253,3 & $(2,3)$ & 263,7 & $(2,9)$ & 263,0 & $(1,9)$ & 281,4 & $(1,4)$ \\
\hline Italija & 222,0 & $(1,7)$ & 237,4 & $(4,5)$ & 258,4 & $(1,7)$ & 275,2 & $(2,2)$ & 272,8 & $(2,8)$ & 286,9 & $(2,9)$ \\
\hline Japonska & 238,3 & $(3,3)$ & 245,3 & $(5,8)$ & 278,1 & $(1,4)$ & 287,3 & $(1,8)$ & 299,2 & $(1,4)$ & 311,3 & $(1,1)$ \\
\hline Koreja & 211,5 & $(2,0)$ & 230,7 & $(3,1)$ & 256,2 & $(1,2)$ & 269,7 & $(1,6)$ & 279,1 & $(1,6)$ & 288,1 & $(1,5)$ \\
\hline Nizozemska & 238,0 & $(2,3)$ & 253,1 & $(2,7)$ & 279,1 & $(1,9)$ & 288,3 & $(1,4)$ & 300,5 & $(2,9)$ & 310,7 & $(1,5)$ \\
\hline Norveška & 228,5 & $(3,8)$ & 235,7 & $(5,4)$ & 269,0 & $(1,8)$ & 273,2 & $(2,0)$ & 288,8 & $(2,2)$ & 303,6 & $(1,4)$ \\
\hline Poljska & 215,1 & $(3,0)$ & 235,9 & $(5,9)$ & 248,6 & $(1,3)$ & 263,0 & $(2,2)$ & 280,1 & $(1,9)$ & 291,3 & $(1,7)$ \\
\hline Slovaška & 216,0 & $(2,7)$ & 249,3 & $(8,6)$ & 270,6 & $(0,9)$ & 289,2 & $(2,2)$ & 300,0 & $(2,2)$ & 308,4 & $(2,0)$ \\
\hline Španija & 213,9 & $(1,4)$ & 232,2 & $(2,0)$ & 251,0 & $(2,0)$ & 262,8 & $(2,0)$ & 270,4 & $(1,8)$ & 281,1 & $(1,2)$ \\
\hline Švedska & 230,5 & $(3,2)$ & 253,0 & $(4,0)$ & 263,5 & $(2,0)$ & 279,5 & $(1,5)$ & 292,5 & $(2,7)$ & 310,9 & $(1,1)$ \\
\hline VB & 203,6 & $(3,0)$ & 221,9 & $(5,7)$ & 249,1 & $(1,8)$ & 267,2 & $(1,8)$ & 274,7 & $(2,8)$ & 292,6 & $(1,9)$ \\
\hline ZDA & 184,6 & $(2,9)$ & 199,8 & $(6,2)$ & 232,7 & $(2,2)$ & 252,4 & $(2,0)$ & 265,6 & $(2,4)$ & 285,2 & $(1,8)$ \\
\hline Povprečje & 221,2 & $(0,6)$ & 238,0 & $(1,1)$ & 260,4 & $(0,4)$ & 273,7 & $(0,4)$ & 285,2 & $(0,5)$ & 298,8 & $(0,4)$ \\
\hline
\end{tabular}

Opomba: Nižja izobrazba zajema stopnje ISCED: 1, 2 in 3C kratki p. Srednja izobrazba zajema stopnje ISCED: 3A, 3B, 3C dolgi $p$ in 4. Višja izobrazba zajema stopnje ISCED: 5A, 5B in 6.

Vir: Survey of Adults Skills (PIAAC, 2012).

Tabela pokaže, da so največje razlike v matematičnih spretnostih pri tistih z nižjo stopnjo izobrazbe $(16,8)$, medtem ko so pri srednji in višji razlike skoraj izenačene (13,3 pri srednji in 13,6 pri višji). Glede na višje povprečje pri višjih stopnjah izobrazbe lahko sklepamo, da so v deležu razlike med višje izobraženimi manjše. Tudi v tem primeru smo posebej analizirali podatke za Češko, kjer so se največje razlike v matematičnih spretnostih spet pokazale pri nižje izobraženih $(15,4)$, nekoliko manjše pri srednje izobraženih $(9,8)$ in najmanjše pri višje izobraženih $(8,4)$. Za Italijo podatki kažejo največje razlike pri srednje izobraženih $(16,8)$, sledijo nižje $(15,4)$ in višje izobraženi $(14,1)$. Tako kot pri bralnih spretnostih se je tudi tukaj pokazalo, da so razlike v italijanskem primeru večje in v češkem manjše. Na podlagi prikazanih podatkov bi lahko sklepali, da je na Češkem vpliv vključenosti v neformalno izobraževanje po zaključku šolanja manjši kot v Italiji, pri čemer je tudi splošna raven doseženih spretnosti na Češkem višja. Ostane nam še pregled tretjega sklopa, se pravi razvoja spretnosti reševanja problemov v tehnološko bogatih okoljih glede na stopnjo izobrazbe. Rezultate za vključene države prikazuje naslednja tabela. 
Tabela 1.3: Razlike $v$ spretnostih reševanja problemov $v$ tehnološko bogatih okoljih po stopnji izobrazbe glede na vključenost v neformalno izobraževanje (povprečja, starost 16-65 let)

\begin{tabular}{|c|c|c|c|c|c|c|c|c|c|c|c|c|}
\hline \multirow[b]{3}{*}{ DRŽAVA } & \multicolumn{4}{|c|}{ Nižja izobrazba } & \multicolumn{4}{|c|}{ Srednja izobrazba } & \multicolumn{4}{|c|}{ Višja izobrazba } \\
\hline & \multicolumn{2}{|c|}{ ni vključen } & \multicolumn{2}{|c|}{ vključen } & \multicolumn{2}{|c|}{ ni vključen } & \multicolumn{2}{|c|}{ vključen } & \multicolumn{2}{|c|}{ ni vključen } & \multicolumn{2}{|l|}{ vključen } \\
\hline & $M$ & S.E. & $M$ & S.E. & M & S.E. & $M$ & S.E. & $M$ & S.E. & $M$ & S.E. \\
\hline Belgija & 241,39 & $(2,8)$ & 250,99 & $(4,8)$ & 270,70 & $(1,4)$ & 275,86 & $(2,0)$ & 290,89 & $(2,0)$ & 298,07 & $(1,3)$ \\
\hline Kanada & 239,96 & $(2,3)$ & 251,15 & $(3,8)$ & 275,51 & $(1,7)$ & 288,13 & $(1,7)$ & 278,82 & $(1,5)$ & 296,95 & $(1,1)$ \\
\hline Češka & 258,01 & $(5,4)$ & 273,30 & $(9,2)$ & 270,36 & $(2,3)$ & 281,84 & $(1,9)$ & 294,78 & $(3,4)$ & 302,34 & $(2,7)$ \\
\hline Danska & 253,58 & $(2,9)$ & 259,37 & $(3,7)$ & 269,46 & $(1,8)$ & 281,56 & $(1,2)$ & 286,99 & $(2,2)$ & 299,46 & $(1,1)$ \\
\hline Estonija & 252,83 & $(2,8)$ & 261,48 & $(4,6)$ & 265,34 & $(1,9)$ & 281,01 & $(1,9)$ & 273,11 & $(1,9)$ & 286,04 & $(1,5)$ \\
\hline Finska & 257,79 & $(3,3)$ & 262,29 & $(4,4)$ & 280,49 & $(2,1)$ & 287,94 & $(1,7)$ & 291,52 & $(2,1)$ & 299,45 & $(1,3)$ \\
\hline Nemčija & 254,62 & $(4,0)$ & 267,69 & $(5,7)$ & 265,50 & $(1,8)$ & 278,77 & $(1,7)$ & 294,27 & $(2,0)$ & 300,75 & $(1,6)$ \\
\hline Irska & 230,46 & $(3,4)$ & 238,26 & $(4,6)$ & 273,11 & $(2,5)$ & 279,81 & $(2,5)$ & 279,22 & $(1,5)$ & 288,13 & $(1,3)$ \\
\hline Japonska & 258,77 & $(7,8)$ & 263,21 & $(10,4)$ & 282,25 & $(2,3)$ & 288,48 & $(2,7)$ & 295,21 & $(1,9)$ & 307,95 & $(1,4)$ \\
\hline Koreja & 240,71 & $(4,7)$ & 254,09 & $(5,5)$ & 270,53 & $(1,8)$ & 283,05 & $(1,8)$ & 281,85 & $(1,7)$ & 292,00 & $(1,3)$ \\
\hline Nizozemska & 252,47 & $(1,9)$ & 264,14 & $(2,2)$ & 284,33 & $(2,0)$ & 288,53 & $(1,5)$ & 298,31 & $(2,6)$ & 306,03 & $(1,5)$ \\
\hline Norveška & 247,48 & $(3,2)$ & 264,97 & $(4,8)$ & 272,87 & $(1,7)$ & 283,62 & $(1,6)$ & 288,54 & $(2,1)$ & 301,09 & $(1,0)$ \\
\hline Poljska & 241,77 & $(7,0)$ & 258,23 & $(8,4)$ & 256,78 & $(2,1)$ & 270,49 & $(2,9)$ & 277,78 & $(2,5)$ & 291,41 & $(2,2)$ \\
\hline Slovaška & 251,28 & $(4,6)$ & 281,92 & $(11,9)$ & 270,20 & $(1,1)$ & 285,03 & $(2,2)$ & 288,77 & $(2,8)$ & 298,44 & $(2,3)$ \\
\hline Švedska & 241,86 & $(3,4)$ & 260,93 & $(4,8)$ & 272,31 & $(1,9)$ & 289,93 & $(1,6)$ & 290,14 & $(2,6)$ & 307,84 & $(1,3)$ \\
\hline VB & 240,96 & $(3,1)$ & 242,52 & $(5,6)$ & 265,09 & $(1,6)$ & 279,72 & $(1,5)$ & 288,93 & $(2,1)$ & 299,72 & $(1,5)$ \\
\hline ZDA & 237,44 & $(3,8)$ & 241,44 & $(6,5)$ & 259,63 & $(1,8)$ & 274,71 & $(2,3)$ & 279,03 & $(1,9)$ & 293,59 & $(1,7)$ \\
\hline Povprečje & 247,14 & $(1,0)$ & 258,59 & $(1,6)$ & 270,85 & $(0,5)$ & 282,26 & $(0,5)$ & 286,95 & $(0,5)$ & 298,19 & $(0,4)$ \\
\hline
\end{tabular}

Opomba: Nižja izobrazba zajema stopnje ISCED: 1, 2 in 3C kratki p. Srednja izobrazba zajema stopnje ISCED: 3A, 3B, 3C dolgi $p$ in 4. Višja izobrazba zajema stopnje ISCED: 5A, 5B in 6.

Vir: Survey of Adults Skills (PIAAC, 2012).

Podatki v tabeli nam kažejo, da so razlike med tistimi, ki so vključeni v neformalno izobraževanje, in tistimi, ki niso, majhne (11,45 pri nižje, 11,41 pri srednje in 11,24 pri višje izobraženih). Če pogledamo še podatke za Češko (za Italijo nam jih ni uspelo dobiti), je slika nekoliko drugačna. V celoti je Češka precej nad povprečjem vključenih držav, so pa razlike med vključenimi in nevključenimi $\mathrm{v}$ formalno izobraževanje po stopnjah izobrazbe večje, kot je povprečje. Največje so pri nižje izobraženih $(15,29)$, manjše pri srednje izobraženih $(11,48)$ in najmanjše pri višje izobraženih $(7,56)$. Za Češko torej velja, da je pri razmeroma visokih dosežkih pri reševanju problemov vpliv neformalnega izobraževanja na to skupino spretnosti v celoti večji kot pri povprečju - z izjemo višje izobraženih, kjer so se te razlike pokazale za manjše kot v povprečju. Očitno je na Češkem pri manj izobraženih dodatno vključevanje $\mathrm{v}$ izobraževanje pomembnejši dejavnik kot pri višje izobraženih, medtem ko za povprečje vključenih držav tega ne bi mogli trditi.

\section{Razlike $v$ izmerjenih spretnostih glede na to, ali je bilo neformalno izobraževanje namenjeno zadovoljevanju potreb dela in poklica po doseženi izobrazbi}

V prejšnjem poglavju smo ugotavljali, da obstajajo velike razlike v izmerjenih spretnostih glede na to, ali so bili anketiranci po končanem formalnem izobraževanju vključeni $\mathrm{v}$ različne oblike neformalnega izobraževanja ali ne. Kot smo pričakovali, se je pokazalo, da ima vključenost $\mathrm{v}$ neformalno izobraževanje pozitivne učinke na razvoj kot tudi na ohranjanje posameznih vrst spretnosti. 
Z vključevanjem v neformalno izobraževanje po končanem šolanju posamezniki zadovoljujejo različne potrebe. Za namen naše analize jih bomo razdelili v dve skupini, in sicer na potrebe, ki so v funkciji poklica in dela, in na potrebe, ki ne izhajajo iz poklicnega dela. Zato bomo vključevanje v neformalno izobraževanje, ki je v funkciji poklica in dela, ločili od vključevanja v vse druge oblike neformalnega izobraževanja. S tem bomo dobili izhodišče za odgovor na vprašanje, ali so med tistimi, ki se vključujejo v neformalno izobraževanje zaradi potreb poklica, in tistimi, ki se vanj vključujejo mimo njih, opazne razlike v izmerjenih temeljnih spretnostih na različnih področjih. Analizo bomo izvedli po stopnjah izobrazbe, in to za povprečje vseh vključenih držav in posebej za dve izbrani državi. V tem poglavju bomo izbrali po velikosti nam podobni, po razvitosti pa različni državi, Slovaško in Irsko.

Najprej si bomo pogledali, kako se kažejo razlike v doseženih ravneh spretnosti glede na namen vključenosti v neformalno izobraževanje pri tistih z nižjo izobrazbo. Podatki so zajeti v spodnji tabeli.

Tabela 2.1: Razlike $v$ spretnostih glede na vključenost $v$ neformalno izobraževanje po namenu - nižja izobrazba (povprečja, starost 16-65 let)

\begin{tabular}{|c|c|c|c|c|c|c|c|c|c|c|c|c|}
\hline \multirow[b]{3}{*}{ DRŽAVA } & \multicolumn{4}{|c|}{ Besedilne spretnosti } & \multicolumn{4}{|c|}{ Matematične spretnosti } & \multicolumn{4}{|c|}{$\begin{array}{l}\text { Spretnosti reševanja } \\
\text { problemov v TBO }\end{array}$} \\
\hline & \multicolumn{2}{|c|}{ NFI - delo } & \multicolumn{2}{|c|}{ NFI - drugo } & \multicolumn{2}{|c|}{ NFI - delo } & \multicolumn{2}{|c|}{$\mathrm{NFI}$ - drugo } & \multicolumn{2}{|c|}{ NFI - delo } & \multicolumn{2}{|c|}{$\mathrm{NFI}$ - drugo } \\
\hline & $M$ & S.E. & $M$ & S.E. & M & S.E. & M & S.E. & M & S.E. & M & S.E. \\
\hline Belgija & 252,7 & $(5,4)$ & 242,4 & $(9,2)$ & 258,8 & $(5,8)$ & 240,8 & $(10,7)$ & 255,7 & $(6,1)$ & 239,3 & 10,6 \\
\hline Kanada & 241,2 & $(4,6)$ & 238,1 & $(7,4)$ & 231,1 & $(5,1)$ & 224,2 & $(8,5)$ & 250,0 & $(4,2)$ & 249,8 & 11,6 \\
\hline Češka & 261,0 & $(13,0)$ & 251,2 & $(10,2)$ & 251,1 & $(11,8)$ & 259,0 & $(16,0)$ & 281,2 & $(12,1)$ & 266,2 & 18,4 \\
\hline Danska & 249,3 & $(3,9)$ & 231,3 & $(6,4)$ & 257,1 & $(3,9)$ & 234,4 & $(6,1)$ & 266,7 & $(4,8)$ & 251,5 & 7,0 \\
\hline Estonija & 255,0 & $(4,9)$ & 268,4 & $(7,9)$ & 248,8 & $(4,3)$ & 256,5 & $(8,7)$ & 256,9 & $(5,5)$ & 279,7 & 9,6 \\
\hline Finska & 265,9 & $(5,1)$ & 245,8 & $(9,2)$ & 260,5 & $(5,2)$ & 244,6 & $(10,4)$ & 268,2 & $(4,7)$ & 254,7 & 9,1 \\
\hline Francija & 243,1 & $(3,7)$ & 216,5 & $(6,9)$ & 233,4 & $(3,7)$ & 201,0 & $(7,9)$ & & & & \\
\hline Nemčija & 252,1 & $(5,7)$ & 227,3 & $(10,4)$ & 247,4 & $(6,2)$ & 208,2 & $(12,8)$ & 270,5 & $(7,3)$ & 268,7 & 10,8 \\
\hline Irska & 238,4 & $(3,2)$ & 224,6 & $(9,8)$ & 228,3 & $(4,5)$ & 211,4 & $(9,9)$ & 239,7 & $(4,7)$ & 244,7 & 11,3 \\
\hline Italija & 236,9 & $(5,4)$ & 239,3 & $(9,8)$ & 234,5 & $(6,5)$ & 238,2 & $(11,4)$ & & & & \\
\hline Japonska & 261,5 & $(8,7)$ & 266,7 & $(8,9)$ & 247,0 & $(7,7)$ & 253,6 & $(8,9)$ & 253,8 & $(12,1)$ & 268,3 & 19,8 \\
\hline Koreja & 244,7 & $(4,4)$ & 246,6 & $(4,7)$ & 231,2 & $(4,2)$ & 231,9 & $(5,2)$ & 250,0 & $(7,6)$ & 270,7 & 8,6 \\
\hline Nizozemska & 263,6 & $(3,2)$ & 238,5 & $(6,7)$ & 260,8 & $(3,4)$ & 232,5 & $(7,2)$ & 269,4 & $(2,7)$ & 249,8 & 6,2 \\
\hline Norveška & 252,4 & $(6,5)$ & 220,8 & $(15,9)$ & 244,5 & $(6,5)$ & 198,8 & $(19,9)$ & 265,3 & $(5,6)$ & 270,1 & 14,5 \\
\hline Poljska & 245,7 & $(8,1)$ & 259,8 & $(9,5)$ & 235,3 & $(9,0)$ & 245,4 & $(11,2)$ & 254,4 & $(11,0)$ & 266,7 & 15,7 \\
\hline Slovaška & 244,6 & $(11,7)$ & 262,7 & $(13,4)$ & 245,5 & $(10,1)$ & 244,9 & $(14,9)$ & 267,3 & $(12,2)$ & 295,6 & 25,7 \\
\hline Španija & 238,6 & $(2,6)$ & 237,3 & $(3,5)$ & 235,4 & $(2,7)$ & 227,1 & $(3,9)$ & & & & \\
\hline Švedska & 260,9 & $(5,0)$ & 247,1 & $(6,6)$ & 257,9 & $(5,8)$ & 241,3 & $(5,5)$ & 263,5 & $(6,3)$ & 257,3 & 8,9 \\
\hline Velika Britanija & 230,8 & $(8,7)$ & 228,8 & $(21,5)$ & 220,7 & $(7,3)$ & 216,8 & $(18,6)$ & 239,6 & $(8,2)$ & 251,9 & 12,5 \\
\hline ZDA & 216,8 & $(7,1)$ & 217,9 & $(11,0)$ & 199,6 & $(8,3)$ & 190,9 & $(12,5)$ & 241,4 & $(9,1)$ & 242,6 & 17,8 \\
\hline Povprečje & 247,8 & $(1,5)$ & 240,6 & $(2,3)$ & 241,5 & $(1,5)$ & 230,1 & $(2,5)$ & 258,4 & $(1,9)$ & 260,4 & 3,3 \\
\hline
\end{tabular}

Opomba: Nižja izobrazba zajema stopnje ISCED: 1, 2 in 3 C kratki p.

»NFI - delo« je program neformalnega izobraževanja, povezan z delom, ki ga opravlja anketiranec; »NFI - drugo« je program neformalnega izobraževanja, ki ni bil povezan z delom, ki ga opravlja anketiranec.

Vir: Survey of Adults Skills (PIAAC, 2012). 
Iz tabele je razvidno, da ima vključenost $\mathrm{v}$ neformalno izobraževanje glede na potrebe poklica ali mimo njih ambivalenten vpliv na dosežene spretnosti. Za celoto lahko pri nižji izobrazbi ugotavljamo pozitiven vpliv neformalnega izobraževanja $\mathrm{v}$ funkciji poklica pri besedilnih in matematičnih spretnostih (razlika je 7,2 pri besedilnih in 11,4 pri matematičnih spretnostih), medtem ko je situacija obrnjena pri reševanju problemov v tehnološko bogatih okoljih, kjer so tisti, ki so bili v neformalno izobraževanje vključeni mimo potreb dela, dosegli boljše rezultate (razlika je 2,0).

Da gre za ambivalentno situacijo, kažejo tudi podatki za obe izbrani državi. Tako je za Irsko značilen močnejši pozitiven vpliv neformalnega izobraževanja v funkciji dela pri besedilnih (razlika je 13,8) in matematičnih spretnostih (razlika je 16,9), medtem ko so pri reševanju problemov dosegali boljše rezultate tisti, ki so bili vključeni v neformalno izobraževanje, ki ni bilo v funkciji poklica (razlika je 5,0). Presenetljivi pa so rezultati za Slovaško, kjer so pri tistih, ki so bili v izobraževanje vključeni zaradi potreb poklicnega dela, za malenkost boljši le rezultati pri matematičnih spretnostih (razlika je 0,6 ), medtem ko so precej boljše rezultate pri besedilnih spretnostih $(23,1)$ in spretnostih reševanja problemov (celih 38,3) dosegali tisti, ki so se vključili mimo potreb poklica.

V nadaljevanju si bomo pogledali, kakšne so razlike pri tistih s srednjo izobrazbo. Rezultate kaže naslednja tabela. 
Tabela 2.2: Razlike $v$ spretnostih glede na vključenost $v$ neformalno izobraževanje po namenu - srednja izobrazba (povprečja, starost 16-65 let)

\begin{tabular}{|c|c|c|c|c|c|c|c|c|c|c|c|c|}
\hline \multirow[b]{3}{*}{ DRŽAVA } & \multicolumn{4}{|c|}{ Besedilne spretnosti } & \multicolumn{4}{|c|}{ Matematične spretnosti } & \multicolumn{4}{|c|}{$\begin{array}{l}\text { Spretnosti reševanja } \\
\text { problemov v TBO }\end{array}$} \\
\hline & \multicolumn{2}{|c|}{$\mathrm{NFI}$ - delo } & \multicolumn{2}{|c|}{ NFI - drugo } & \multicolumn{2}{|c|}{ NFI - delo } & \multicolumn{2}{|c|}{ NFI - drugo } & \multicolumn{2}{|c|}{ NFI - delo } & \multicolumn{2}{|c|}{$\mathrm{NFI}$ - drugo } \\
\hline & M & S.E. & M & S.E. & M & S.E. & M & S.E. & M & S.E. & M & S.E. \\
\hline Belgija & 273,9 & $(2,2)$ & 240,8 & $(10,7)$ & 282,2 & $(2,4)$ & 276,3 & $(4,1)$ & 278,6 & $(2,3)$ & 270,1 & 5,1 \\
\hline Kanada & 281,2 & $(1,8)$ & 224,2 & $(8,5)$ & 270,1 & $(2,1)$ & 274,5 & $(4,0)$ & 287,6 & $(1,9)$ & 294,5 & 3,5 \\
\hline Češka & 277,3 & $(1,7)$ & 259,0 & $(16,0)$ & 279,0 & $(1,8)$ & 288,1 & $(4,7)$ & 283,9 & $(2,4)$ & 295,3 & 5,2 \\
\hline Danska & 272,6 & $(1,5)$ & 234,4 & $(6,1)$ & 282,4 & $(1,5)$ & 283,8 & $(3,2)$ & 280,8 & $(1,5)$ & 290,0 & 3,3 \\
\hline Estonija & 279,5 & $(2,0)$ & 256,5 & $(8,7)$ & 277,1 & $(1,7)$ & 285,8 & $(2,7)$ & 279,6 & $(2,5)$ & 298,1 & 2,9 \\
\hline Finska & 291,1 & $(2,2)$ & 244,6 & $(10,4)$ & 283,3 & $(2,1)$ & 285,4 & $(3,6)$ & 287,5 & $(2,0)$ & 293,1 & 3,6 \\
\hline Francija & 264,2 & $(1,6)$ & 201,0 & $(7,9)$ & 258,4 & $(1,8)$ & 269,9 & $(3,5)$ & & & & \\
\hline Nemčija & 271,3 & $(1,9)$ & 208,2 & $(12,8)$ & 274,0 & $(2,0)$ & 274,2 & $(3,4)$ & 279,1 & $(2,0)$ & 285,2 & 4,1 \\
\hline Irska & 278,2 & $(2,6)$ & 211,4 & $(9,9)$ & 267,9 & $(2,9)$ & 258,9 & $(8,7)$ & 279,0 & $(3,0)$ & 293,8 & 6,2 \\
\hline Italija & 275,8 & $(2,5)$ & 238,2 & $(11,4)$ & 279,3 & $(2,8)$ & 267,4 & $(4,9)$ & & & & \\
\hline Japonska & 293,6 & $(2,0)$ & 253,6 & $(8,9)$ & 288,9 & $(2,5)$ & 285,4 & $(4,1)$ & 288,3 & $(3,3)$ & 295,4 & 5,9 \\
\hline Koreja & 279,1 & $(1,8)$ & 231,9 & $(5,2)$ & 269,7 & $(2,1)$ & 273,8 & $(2,6)$ & 282,9 & $(2,4)$ & 289,3 & 3,0 \\
\hline Nizozemska & 290,5 & $(1,5)$ & 232,5 & $(7,2)$ & 287,5 & $(1,6)$ & 291,1 & $(4,2)$ & 288,9 & $(1,7)$ & 286,4 & 3,8 \\
\hline Norveška & 274,6 & $(1,8)$ & 198,8 & $(19,9)$ & 273,2 & $(2,1)$ & 276,7 & $(4,8)$ & 282,8 & $(1,8)$ & 293,2 & 5,1 \\
\hline Poliska & 267,0 & $(2,5)$ & 245,4 & $(11,2)$ & 262,0 & $(2,9)$ & 270,7 & $(3,6)$ & 269,3 & $(3,6)$ & 280,2 & 4,6 \\
\hline Slovaška & 285,0 & $(2,0)$ & 244,9 & $(14,9)$ & 291,2 & $(2,5)$ & 283,2 & $(6,1)$ & 286,6 & $(2,6)$ & 283,9 & 5,2 \\
\hline Španija & 260,9 & $(2,7)$ & 227,1 & $(3,9)$ & 259,3 & $(2,5)$ & 269,3 & $(4,1)$ & & & & \\
\hline Švedska & 281,7 & $(1,9)$ & 241,3 & $(5,5)$ & 280,1 & $(2,1)$ & 281,8 & $(4,2)$ & 288,7 & $(2,1)$ & 299,2 & 2,8 \\
\hline Velika Britanija & 278,1 & $(1,9)$ & 216,8 & $(18,6)$ & 268,3 & $(2,0)$ & 267,4 & $(6,1)$ & 281,2 & $(1,8)$ & 279,8 & 4,5 \\
\hline ZDA & 269,9 & $(2,0)$ & 190,9 & $(12,5)$ & 252,3 & $(2,4)$ & 263,5 & $(6,1)$ & 273,9 & $(2,5)$ & 287,8 & 4,4 \\
\hline Povprečje & 277,3 & $(0,5)$ & 230,1 & $(2,5)$ & 274,3 & $(0,5)$ & 276,4 & $(1,0)$ & 282,3 & $(0,6)$ & 289,1 & 1,1 \\
\hline
\end{tabular}

Opomba: Srednja izobrazba zajema stopnje ISCED: 3A, 3B, 3C dolgi p in 4.

»NFI - delo« je program neformalnega izobraževanja, povezan z delom, ki ga opravlja anketiranec; »NFI - drugo« je program neformalnega izobraževanja, ki ni bil povezan z delom, ki ga opravlja anketiranec.

Vir: Survey of Adults Skills (PIAAC, 2012).

Tudi v tem primeru si bomo najprej pogledali povprečje, saj nam bo to razkrilo, kakšen je splošni trend. Podatki kažejo, da je vpliv izobraževanja, povezanega s poklicem, pozitiven le pri besedilnih spretnostih (razlika je celih 47,2), medtem ko je slika obrnjena pri matematičnih spretnostih (razlika 2,1) in pri spretnostih reševanja problemov (razlika 6,8 ), kjer so boljše rezultate dosegali tisti, ki so se vključevali v neformalno izobraževanje mimo potreb poklica. Pri naših dveh izbranih državah je trend v smeri doseganja boljših rezultatov pri tistih, ki so vključeni zaradi potreb poklica, bolj izrazit. Za Slovaško podatki kažejo za bralne spretnosti razliko 40,1, za matematične 8,0 in za spretnosti reševanje problemov 2,7 , vse $\mathrm{v}$ prid tistih, ki so se v izobraževanje vključili v povezavi s potrebami poklica. Pri Irski se je pokazala velika razlika pri besedilnih spretnostih za tiste, ki so se vključevali glede na potrebe poklica (razlika je 66,8), nekoliko manj pri matematičnih spretnostih $(9,0)$, medtem ko so pri spretnostih reševanja problemov boljše rezultate dosegali tisti, ki so se vključevali mimo potreb dela (razlika je 14,8).

Da bi bila slika jasnejša, si poglejmo še, kakšna je situacija pri tistih z višjo izobrazbo. 
Tabela 2.3: Razlike $v$ spretnostih glede na vključenost v neformalno izobraževanje po namenu - višja izobrazba (povprečja, starost 16-65 let)

\begin{tabular}{|c|c|c|c|c|c|c|c|c|c|c|c|c|}
\hline \multirow[b]{3}{*}{ DRŽAVA } & \multicolumn{4}{|c|}{ Besedilne spretnosti. } & \multicolumn{4}{|c|}{ Matematične spretnosti } & \multicolumn{4}{|c|}{$\begin{array}{l}\text { Spretnosti reševanja proble- } \\
\text { mov v TBO }\end{array}$} \\
\hline & \multicolumn{2}{|c|}{ NFI - delo } & \multicolumn{2}{|c|}{ NFI - drugo } & \multicolumn{2}{|c|}{ NFI - delo } & \multicolumn{2}{|c|}{ NFI - drugo } & \multicolumn{2}{|c|}{ NFI - delo } & \multicolumn{2}{|c|}{ NFI - drugo } \\
\hline & $M$ & S.E. & M & S.E. & M & S.E. & M & S.E. & M & S.E. & M & S.E. \\
\hline Belgija & 304,6 & $(1,5)$ & 301,3 & $(3,1)$ & 312,7 & $(1,6)$ & 304,8 & $(3,6)$ & 298,3 & $(1,5)$ & 295,7 & 3,4 \\
\hline Kanada & 298,6 & $(1,1)$ & 299,2 & $(2,0)$ & 291,1 & $(1,2)$ & 293,2 & $(2,4)$ & 297,4 & $(1,2)$ & 298,5 & 2,7 \\
\hline Češka & 298,6 & $(2,6)$ & 311,6 & $(6,4)$ & 310,1 & $(2,8)$ & 310,8 & $(6,6)$ & 302,1 & $(3,3)$ & 308,9 & 4,4 \\
\hline Danska & 296,7 & $(1,1)$ & 289,0 & $(3,9)$ & 306,6 & $(1,3)$ & 297,9 & $(4,0)$ & 300,0 & $(1,4)$ & 297,3 & 3,8 \\
\hline Estonija & 292,7 & $(1,3)$ & 300,6 & $(2,8)$ & 292,6 & $(1,2)$ & 294,4 & $(2,8)$ & 286,2 & $(1,7)$ & 293,0 & 2,6 \\
\hline Finska & 310,6 & $(1,2)$ & 307,4 & $(4,2)$ & 306,5 & $(1,4)$ & 302,9 & $(3,8)$ & 299,4 & $(1,4)$ & 298,2 & 3,3 \\
\hline Francija & 300,5 & $(1,3)$ & 299,4 & $(3,8)$ & 303,1 & $(1,5)$ & 301,8 & $(4,6)$ & & & & \\
\hline Nemčija & 299,4 & $(1,6)$ & 298,2 & $(4,1)$ & 306,7 & $(1,7)$ & 301,8 & $(5,0)$ & 300,6 & $(1,9)$ & 304,3 & 4,1 \\
\hline Irska & 290,0 & $(1,6)$ & 290,9 & $(2,8)$ & 283,2 & $(1,8)$ & 280,7 & $(3,1)$ & 288,9 & $(1,4)$ & 292,1 & 3,3 \\
\hline Italija & 289,3 & $(2,6)$ & 293,2 & $(7,4)$ & 287,7 & $(3,0)$ & 284,6 & $(9,8)$ & & & & \\
\hline Japonska & 316,8 & $(1,1)$ & 316,4 & $(2,8)$ & 313,2 & $(1,4)$ & 307,4 & $(3,3)$ & 309,9 & $(1,7)$ & 304,9 & 4,2 \\
\hline Koreja & 295,5 & $(1,1)$ & 291,8 & $(2,1)$ & 289,2 & $(1,7)$ & 286,8 & $(2,3)$ & 292,9 & $(1,4)$ & 290,9 & 2,6 \\
\hline Nizozemska & 314,9 & $(1,6)$ & 306,8 & $(3,5)$ & 311,9 & $(1,6)$ & 305,5 & $(3,6)$ & 308,6 & $(1,5)$ & 294,9 & 4,4 \\
\hline Norveška & 302,0 & $(1,2)$ & 293,8 & $(4,7)$ & 305,8 & $(1,6)$ & 294,0 & $(5,1)$ & 301,8 & $(1,1)$ & 300,2 & 4,1 \\
\hline Poljska & 299,1 & $(1,8)$ & 300,8 & $(3,8)$ & 292,2 & $(1,8)$ & 289,1 & $(3,5)$ & 289,4 & $(2,5)$ & 298,6 & 5,3 \\
\hline Slovaška & 296,7 & $(2,1)$ & 304,3 & $(5,3)$ & 309,0 & $(2,3)$ & 304,6 & $(6,9)$ & 298,7 & $(2,5)$ & 303,3 & 6,8 \\
\hline Španija & 286,8 & $(1,3)$ & 284,0 & $(3,4)$ & 283,3 & $(1,3)$ & 278,0 & $(3,1)$ & & & & \\
\hline Švedska & 309,8 & $(1,3)$ & 306,8 & $(3,0)$ & 312,2 & $(1,3)$ & 308,5 & $(3,1)$ & 307,8 & $(1,4)$ & 311,0 & 3,0 \\
\hline Velika Britanija & 301,7 & $(1,9)$ & 294,3 & $(4,5)$ & 294,0 & $(2,1)$ & 288,2 & $(5,0)$ & 301,2 & $(1,7)$ & 293,6 & 4,6 \\
\hline ZDA & 296,3 & $(1,7)$ & 299,3 & $(3,1)$ & 286,0 & $(1,7)$ & 285,5 & $(3,7)$ & 293,7 & $(1,7)$ & 295,7 & 3,5 \\
\hline Povprečje & 300,0 & $(0,4)$ & 299,4 & $(0,9)$ & 299,9 & $(0,4)$ & 296,0 & $(1,0)$ & 298,6 & $(0,4)$ & 298,9 & 1,0 \\
\hline
\end{tabular}

Opomba: Višja izobrazba zajema stopnje ISCED: 5A, 5B in 6.

»NFI - delo« je program neformalnega izobraževanja, povezan z delom, ki ga opravlja anketiranec; »NFI - drugo« je program neformalnega izobraževanja, ki ni bil povezan z delom, ki ga opravlja anketiranec.

Vir: Survey of Adults Skills (PIAAC, 2012).

Podatki v tabeli kažejo, da so za povprečje vključenih držav razlike minimalne. Opaziti je rahel pozitiven učinek pri vključenih zaradi potreb poklicnega dela pri besedilnih (razlika je 0,6 ) in matematičnih spretnostih (razlika je 3,9) in, obratno, minimalna razlika v prid vključenih mimo potreb dela pri spretnostih reševanja problemov v TBO (razlika 0,3 ). Tudi v rezultatih za Irsko razlike niso velike, kažejo pa na boljše rezultate pri vključenih mimo potreb poklicnega dela za besedilne spretnosti $(7,6)$ in spretnosti reševanja problemov $(8,2)$, medtem ko je pri matematičnih spretnostih razlika v prid vključenih zaradi potreb poklicnega dela $(2,5)$. Pri Slovaški so podatki podobni, le razlike so nekoliko večje, čeprav še vedno razmeroma majhne. Tako so pri besedilnih spretnosti in spretnosti reševanja problemov (razlika 4,6) boljši rezultati za vključene mimo potreb dela (razlika 7,6), medtem ko so pri matematičnih spretnostih nekoliko boljše rezultate tudi na Slovaškem dosegli vključeni zaradi potreb poklicnega dela $(4,4)$. 
Analizo dosežkov glede na to, ali so bili anketiranci vključeni v neformalno izobraževanje glede na potrebe dela in poklica ali mimo njih, lahko sklenemo z ugotovitvijo, da ne moremo govoriti o močno izraženem splošnem trendu. Pri spretnostih reševanja problemov se je pokazalo, da so $\mathrm{v}$ vseh primerih (skupno in $\mathrm{v}$ obeh izbranih državah) dosegali boljše rezultate tisti, ki se v neformalno izobraževanje vključujejo mimo potreb dela in poklica. Posebej izrazite so te razlike na Slovaškem. Očitno je, da so spretnosti reševanja problemov močno odvisne od angažiranosti posameznika mimo potreb dela in poklica ter ob njih in da so zanje bolj kot poklicni angažma pomembne aktivnosti na drugih področjih življenja.

\section{KLJUČNE UGOTOVITVE}

Analiza je pokazala na velik pomen, ki ga ima vključevanje v neformalno izobraževanje, za dosežke na vseh treh področjih, kjer smo merili stopnje spretnosti. Prav tako rezultati kažejo, da je vključevanje v neformalno izobraževanje pri tistih z nižjo izobrazbo imelo bolj pozitivne učinke kot pri tistih s srednjo in višjo. Spet se torej potrjuje, kako velik je pomen vlaganj v izobraževanje pri izobrazbeno prikrajšanih oziroma tistih, ki so šolski sistem zapustili razmeroma zgodaj. Neformalno izobraževanje, ki je lahko v funkciji dela in poklica, in drugo neformalno izobraževanje ne kažeta enoznačnega vpliva na razvoj posameznih spretnosti. Je pa zanimivo, da se pri reševanju problemov razkriva, da boljše rezultate praviloma dosegajo tisti, ki so v neformalno izobraževanje vključeni mimo potreb dela. Morda je to posledica večje samoiniciativnosti in vključenosti v različne dejavnosti zunaj dela, ki zajemajo tudi uporabo informacijsko-komunikacijske tehnologije. Čeprav še nimamo podatkov za Slovenijo, je treba pri načrtovanju in neposrednem vključevanju v neformalno izobraževanje posebno skrb nameniti tistim z nižjo izobrazbo. Domnevamo, da bodo namreč tudi podatki za Slovenijo pokazali podobno situacijo, kot so jo v analiziranih državah in tudi v celotnem vzorcu držav.

Pomembna ugotovitev analize podatkov držav, ki so bile vključene prvi krog raziskave PIAAC, je, da neformalnemu izobraževanju, vezanemu na poklic in delo, ne kaže namenjati večje pozornosti kot tistemu, ki poteka mimo teh potreb. To je pomembno zlasti pri načrtovanju sredstev za neformalno izobraževanje, saj ne velja a priori, da neformalno izobraževanje $\mathrm{v}$ funkciji dela in poklica bolj pripomore $\mathrm{k}$ razvoju posameznih vrst spretnosti. Seveda pa bomo morali za bolj eksplicitna priporočila počakati še na slovenske rezultate in jih skrbno analizirati z vidika vloge neformalnega izobraževanja. 


\section{LITERATURA}

Ardouin, T. (2006). Ingénierie de formation pour l'entreprise : Analyser, Concevoir, Réaliser, Evaluer. Paris: Dunod.

Bjørnåvold, J. (2001). Assurer la transparence des compétences. Luxembourg: CEDEFOP.

Cvetek, S. (2003). Profesionalnost in profesionalizem v poučevanju in izobraževanju za poklic učitelja. Sodobna pedagogika, 3, 78-97.

Delamare Le Deist, F. in Winterton, J. (2005). What is Competence. Human Resource Development International, 8(1), 27-46.

Glossary of Labour Market Terms and Standards (1997). Torino: ETF.

Kelava, P. (2003). Pravičnost v dostopu do izobraževanja glede na izobrazbeni izvor posameznika in njegove družine. Sodobna pedagogika, 4, 86-103.

Key Competences for Lifelong Learning - A European Framework (2006). Official Journal of the European Union, 30. 12. 2006.

Kirschner, P. A. in Thijsesen J. (2005). Competency development and employability. Lifelong learning in Europe, 10(2), 70-75.

Kondrad, E. (1999). Delovne kariere: izziv za izobraževanje. Sodobna pedagogika, 2, 80-91.

Krajnc, A. (1979). Izobraževanje ob delu. Ljubljana: DDU.

Le Ny, J. F. (1994). Connaissance. Dictionaire encyclopedique de l'education et de la formation. Paris: Nathan.

Malglaive, G., 1994. Les rapports entre savoir et pratique dans le développement des capacités d'apprentissage chez les adultes. Education permanente, 2,125-134.

Memorandum o vseživljenjskem učenju. (2000). Bruselj: Komisija evropske skupnosti.

Minet, F. (2005). Competence: de la definition à l'utilisation. Elaborer des référentiels de compétences. Paris: Anact.

Mohorčič Špolar, V. A., Ivančič, A., Mirčeva, J., Možina, E., Radovan, M., Vilič Klenovšek, T. in Manoilov, M. (2001). Udeležba prebivalcev Slovenije v izobraževanju odraslih. Ljubljana: Andragoški center Slovenije.

Možina, E. (2000). Pismenost odraslih v Sloveniji - pozabljen kapital. V M. Velikonja (ur.), Pismenost, participacija in družba znanja (str. 18-41). Ljubljana: Andragoški center Slovenije.

Muršak, J. (2012). Temeljni pojmi poklicnega in strokovnega izobraževanja. Ljubljana: CPI.

Nonanka I. in Takuchi, H. (1995). The knowledge-creating company. Oxford: University press.

OECD (2002). Definition and Selection of Competencies (DeSeCo). Theoretical and conceptual foundations. Pridobljeno s http://www.oecd.org/edu/skills-beyond-school/definitionandselectionofcompetenciesdeseco.htm.

Ozvald, K. (1922). Kaj je in kaj ni ljudska univerza. Popotnik, XLII,1-11.

Ozvald, K. (1927). Kulturna pedagogika. Kažipot za umevanje včlovečevanja. Ljubljana: Slovenska šlska matica.

Ozvald, K. (1928). Prispevek k idejnim temeljem šolskega zakona. Pedagoški zbornik Slovenske šolske matice, 24(1), 10-15.

PISA 2012. (2013). Program mednarodne primerjave dosežkov učencev. Ljubljana: Pedagoški inštitut. Pridobljeno s http://www.pei.si/UserFilesUpload/file/raziskovalna_dejavnost.

Resolucija o nacionalnem programu izobraževanja odraslih v RS za obdobje 2013-2020. (2013). Uradni list RS, 90, 9753-9780.

Robichon, M. in U. Josenhaus, 2004. Comment évaluer les compétences à des fins de cerification? Education permanente,158, 87-98. 
Sardoč, M. (2013). Enake (izobraževalne) možnosti in družbena neenakost. Sodobna pedagogika, 2, 48-63.

The European Qualifications Framework for Lifelong Learning (2008). Luxembourg: Office for Official Publications of the European Communities.

Vidmar, T. (2006). Vseživljenjsko učenje pred svojo sodobno konceptualizacijo. Sodobna pedagogika, $3,28-49$.

Wesselink, R. (2007). Competence-based VET as seen by Dutch researhers. European journal of vocational training. 40(1), str. 38-51.

Wittorski, R. (1998). De la fabrication des competénces. Educaction permanente,135, 57-71. 